\title{
APPLICATION OF THE RANDOM AMPLIFIED POLYMORPHIC DNA USING THE POLYMERASE CHAIN REACTION FOR EFFICIENT ELIMINATION OF DUPLICATE STRAINS IN MICROBIAL SCREENING
}

\author{
III. BACTERIA
}

\author{
Hitomi Tanaka, Sayoko Sawairi* and Toru Okuda \\ Department of Microbiology and Taxonomy, \\ Nippon Roche Research Center, \\ 200 Kajiwara, Kamakura, Kanagawa 247, Japan \\ (Received for publication September 27, 1993)
}

\begin{abstract}
Random amplified polymorphic DNA (RAPD) analysis was evaluated for the selection and elimination of bacterial strains used in microbial screening. For this pilot study we used eight bacterial strains producing fragin and two Pseudomonas fragi strains, which are often isolated during the screening. A dendrogram constructed by the statistical analysis using parsimony, PAUP, based on the band patterns of RAPD with primer R28 was in good correlation with the results of DNA - DNA hyḅridization, HPLC analysis of metabolites, and conventional morphological and physiological characterization. RAPD was also applicable to a wide range of bacteria. This rapid selection system by RAPD was a very useful tool for excluding similar bacterial isolates encountered during screening.
\end{abstract}

Bacteria are an important source for new drug screening. It is essential for the discovery of new compounds to screen a large number of different strains. However, it is more difficult to select bacterial strains than fungal and actinomycete strains because of their simple morphology. Therefore, the selection of bacterial strains on the basis of traditional taxonomic methods is labour-intensive. A simpler and more effective selection method is necessary to perform high quality screening.

We have therefore applied the fingerprint identification system by the random amplified polymorphic DNA (RAPD) as a convenient procedure to evaluate strains using fragin producers that were isolated during our screening program. A wider range of bacterial genera were also evaluated by this method.

\section{Materials and Methods}

Strains

The bacterial strains used are listed in Tables 1 and 2. Pseudomonas strains were isolated from Japanese soil samples. Fragin was isolated from Pseudomonas fragi in 1969 by Murayama et al. ${ }^{1)}$ Two reference strains of Ps. fragi were used for our study. There was no information of available on fragin production in the reference strains. Other reference strains, including type strains, were purchased from the Institute for Fermentation, Osaka, Japan, (IFO) and the American Type Culture Collection, Rockville, U.S.A., (ATCC).

Taxonomic Characterization

Morphological and physiological characteristics of Pseudomonas strains were examined according to PaLLERONI. ${ }^{2}$

Table 1. Bacterial strains studied.

\begin{tabular}{lll}
\hline \multicolumn{1}{c}{ Species } & \multicolumn{1}{c}{ Strain } & \multicolumn{1}{c}{ Source } \\
\hline Pseudomonas fragi & IFO 3458 & \\
Ps. fragi & IFO 12049 & \\
Pseudomonas sp. & NR 2996 & Soil, Yamagata, Japan \\
Pseudomonas sp. & NR 2997 & Soil, Gumma, Japan \\
Pseudomonas sp. & NR 2998 & Soil, Gumma, Japan \\
Pseudomonas sp. & NR 2999 & Soil, Kyoto, Japan \\
Pseudomonas sp. & NR 3000 & Soil, Kagoshima, Japan \\
Pseudomonas sp. & NR 3001 & Soil, Aichi, Japan \\
Pseudomonas sp. & NR 3002 & Soil, Aichi, Japan \\
Pseudomonas sp. & NR 3003 & Soil, Aichi, Japan \\
\hline
\end{tabular}

$\mathrm{T}$, type strain. 
Table 2. Various bacterial strains used for RAPD with primer R28.

\begin{tabular}{|c|c|c|c|}
\hline Species & Strain & Species & Strain \\
\hline Acinetobacter calcoaceticus & IFO 13006 & Rhizobium leguminosarum & IFO 14168 \\
\hline Aeromonas hydrophila & IFO 3820 & Serratia liquefaciens & IFO 12979 \\
\hline Agrobacterium tumefaciens & IFO 3058 & Sphingobacterium spiritivorum & $\operatorname{ATCC} 33861^{\mathrm{T}}$ \\
\hline Shewanella putrefaciens & IFO $3908^{\mathrm{T}}$ & Xanthomonas campestris & IFO 13551 \\
\hline Azotobacter chroococum & IFO 12994 & Arthrobacter ramosus & IFO $12958^{\mathrm{T}}$ \\
\hline Escherichia coli & NIHJ JC-2 & Bacillus laterosporus & $\operatorname{ATCC~} 64^{\mathrm{T}}$ \\
\hline Erwinia herbicola & IFO 12686 & B. licheniformis & IFO $12200^{\mathrm{T}}$ \\
\hline Flavobacterium meningosepticum & IFO $12535^{\mathrm{T}}$ & B. pumilus & IFO $12092^{\mathrm{T}}$ \\
\hline Proteus vulgaris & IFO 3167 & B. subtilis & IFO $13719^{\mathbf{T}}$ \\
\hline P. vulgaris & ATCC 6898 & Corynebacterium glutamicum & ATCC 13869 \\
\hline P. vulgaris & IFO $3851^{\mathrm{T}}$ & C. michiganens & IFO 12471 \\
\hline$P$. vulgaris & ATCC 6380 & Micrococcus luteus & IFO $3333^{T}$ \\
\hline Pseudomonas aerginosa & A3 & $M$. roseus & IFO $3768^{\mathrm{T}}$ \\
\hline Ps. caryophylli & IFO 12952 & Staphylococcus aureus & 209P JC-1 \\
\hline Comamonas testosteroni & ATCC $11996^{\mathrm{T}}$ & & \\
\hline
\end{tabular}

${ }^{\mathrm{T}}$, type strain.

Analysis of Metabolites by HPLC

Extracts from Pseudomonas cultures were analyzed by HPLC. The seed and fermentation medium contained the following (w/v): $1 \%$ glucose, $1 \%$ dextrin, $1 \%$ Pharmamedia, $1 \%$ S-3 meat, $0.06 \% \mathrm{~K}_{2} \mathrm{HPO}_{4}$, $0.025 \% \mathrm{KH}_{2} \mathrm{PO}_{4}$, and an antifoaming agent (Nissan Disfoam CA-115). The bacterial cell suspension was inoculated into $100 \mathrm{ml}$ of the seed medium in a $500-\mathrm{ml}$ baffled Erlenmeyer flask and cultured on a rotary shaker $(220 \mathrm{rpm})$ at $27^{\circ} \mathrm{C}$ for one day. Then $0.1 \mathrm{ml}$ of the seed culture was transferred into $100 \mathrm{ml}$ of the fermentation medium in a 500-ml baffled Erlenmeyer flask and cultured for 3 days under the same conditions as described above. The culture broth was extracted with ethyl acetate and the extract was concentrated under reduced pressure. The residual sample was dissolved in $1 \mathrm{ml}$ of methanol. Analyses were conducted on a $150 \times 4.6 \mathrm{~mm}$ ODS $\mathrm{C}_{18}$ column (YMC pack A301) HPLC system $600 \mathrm{E}$ with a photodiode array detector (Waters). A gradient solvent system (with solvent $\mathrm{A}=$ water and solvent $\mathbf{B}=0.05 \%$ trifluoroacetic acid in acetonitrile) was used. The gradient program was as follows: the initial percentage of solvent $\mathrm{B}$ was $10 \%$, which was raised to $50 \%$ in 30 minutes, then to $90 \%$ in 10 minutes, held at $90 \%$ for 10 minutes and lowered to $10 \%$ again in 3 minutes, and held at $10 \%$ for 2 minutes at a flow-rate of $2.0 \mathrm{ml} / \mathrm{minute}$ until the next sample injection. ${ }^{3)}$

DNA - DNA Hybridization

A loop of cell mass was inoculated into a $500-\mathrm{ml}$ Erlenmeyer flask containing $100 \mathrm{ml}$ of nutrient broth (Kyokuto) or tripticase soy broth (BBL) supplemented with $0.4 \%$ glycine and cultured at $27^{\circ} \mathrm{C}$ on a rotary shaker at $220 \mathrm{rpm}$. The cells were harvested in exponential growth phase. DNA was extracted from cells according to the method of SAITO and MiURA. ${ }^{4)}$

DNA - DNA hybridization was performed at $45^{\circ} \mathrm{C}$ for 90 minutes by the microplate method according to EZAKI et al. ${ }^{\text {s) }}$

\section{Amplification and Electrophoresis Conditions for RAPD}

Bacterial cells were peeled off from a potato sucrose ager slant surface and completely suspended in $500 \mu \mathrm{l}$ of $10 \mathrm{~mm}$ Tris-1 mm EDTA buffer. About $5 \mu \mathrm{l}$ of $5 \mathrm{~N} \mathrm{NaOH}$ was added to the cell suspension and gently mixed. After centrifugation at $15,000 \mathrm{rpm}$ at $4^{\circ} \mathrm{C}$ for 10 minutes, the aqueous phase $(400 \mu \mathrm{l})$ was dispensed into another microtube. DNA was precipitated in $800 \mu \mathrm{l}$ cold ethanol and centrifuged at $10,000 \mathrm{rpm}$ at $4^{\circ} \mathrm{C}$ for 5 minutes. The crude DNA was dried, dissolved in $100 \mu \mathrm{l}$ of TE buffer, and used as a template for polymerase chain reaction (PCR).

Primers R28 and B1 to B11 were used in this study. ${ }^{6}$

The PCR solution $(50 \mu \mathrm{l})$ contained $1 \times$ reaction buffer (Pro Bio), $2.5 \mathrm{mM} \mathrm{MgCl}_{2}, 200 \mu \mathrm{M}$ each of dNTPs (Takara), $25 \mathrm{ng}$ template DNA, $2.5 \mu \mathrm{m}$ primer and 4 units of Taq DNA polymerase (Pro Bio). Random DNA amplifications were run in a ZYMOREACTER II (Atto) programmed as follows: initial 
and subsequent 30 cycles of denaturation at $94^{\circ} \mathrm{C}$ for 1 minute, annealing at $34^{\circ} \mathrm{C}$ for 1 minute, extension at $72^{\circ} \mathrm{C}$ for 1 minute, and extension at $72^{\circ} \mathrm{C}$ for 10 minutes as the final cycle. The PCR products with $\mathrm{BPB}$-sucrose solution containing the front and origin markers, ${ }^{77}$ were applied to a $5 \%$ polyacrylamide gel with TAE buffer $(0.04 \mathrm{M}$ Tris-acetate and $0.002 \mathrm{M}$ EDTA); electrophoresis was carried out at $50 \mathrm{~V}$ for 90 minutes in Mupid-2 (Advance). The PCR products were stained with ethidium bromide $(1 \mathrm{mg} / \mathrm{ml})$ and detected by a transilluminator ( $302 \mathrm{~nm}$, UVP).

Data analysis

The Rf values of each DNA band were measured by an image analyzer (Millipore). The Rf value was converted to a data matrix consisting of " 0 " or " 1 " according to FUIMORI and OKUDA. ${ }^{7}$ The statistical analysis using parsimony, PAUP (vers. $3.0 \mathrm{~s}),{ }^{8)}$ was used to construct a dendrogram. The dendrogram was obtained using the bootstrap method with a heuristic program search provided by PAUP.

\section{Results and Discussion}

The taxonomic characteristics of our isolates and the reference strains are shown in Table $3 .{ }^{2)}$ These strains were Gram negative non-sporulating rods with a cell size of $0.5 \sim 0.7 \times 1.4 \sim 2.3 \mu \mathrm{m}$, aerobic, and motile with one or several polar flagella. The color of colonies was pale yellow. The oxidase and catalase productions were positive, and the OF test was oxidative. Growth factors were not required. Nitrate reduction was negative except for NR 2996. No PHB accumulation was observed in any strains. On the basis of these characteristics, therefore, the 8 strains belonged to RNA group 1 of the genus Pseudomonas. No fluorescent pigment was produced on KING's B medium. The strains were further divided into two groups, "stutzeri group" containing NR 2996 and NR 3000, which can use glucose for growth, and a group of Ps. alcaligenes containing NR 2997, NR 2998, NR 2999, NR 3001, NR 3002, and NR 3003, which cannot. Homology values based on DNA - DNA hybridization experiments are shown in Table 4. Three major groups were recognized using a criterion of more than seventy percent homology. Within the first group that contained NR 2996 and NR 3000, the strains exhibited a high homology value and were considered as the same species. The six strains that belonged to the group of Ps. alcaligenes, NR 2997, NR 2998, NR 2999, NR 3001, NR 3002, and NR 3003, were one taxon based on their high homology value of DNA hybridization (the second group of DNA homology). NR 2999 has a lower level of similarity to the other strains of the group when DNA of NR 2999 was used as a probe. The six strains, however, formed a compact group according to their DNA relatedness. The two strains of Ps. fragi belonging to the "stutzeri group" had physiological properties that were obviously different from those of the first group in the DNA homology results. These hybridization results were consistent with the morphological data, such as the number of flagella.

Metabolites of the Pseudomonas strains were analyzed by HPLC. Four profiles were observed in the 10 strains. Most production profiles corresponded well to the above taxonomic groups (Fig. 1). The profile of NR 2996, however, differed from that of NR 3000 in the same species. These two strains were distinct. No fragin production was detected from the two reference strains of Ps. fragi.

We compared the band patterns of the PCR products with primer R28 among our isolates and the reference strains (Fig. 2). After Rf values of each band were measured and converted to the " $0-1$ " matrix, a dendrogram was generated by the PAUP (Fig. 3). Four clusters were formed. NR 2997, NR 2998, NR 2999, NR 3001, NR 3002, and NR 3003 showed very similar band patterns and were in the same cluster. The six strains were identical from the RAPD results, which were supported by the HPLC profiles. The RAPD pattern for NR 2996 was different from that of NR 3000. The results of PAPD were consistent 
Table 3. Morphological and physiological characteristics of fragin producers and two Pseudomonas strains.

\begin{tabular}{|c|c|c|c|c|c|c|c|c|c|c|}
\hline Strains & NR 2996 & NR 3000 & NR 2997 & $N R 2778$ & NR 2999 & NR 3001 & NR 3002 & NR 3003 & $\begin{array}{l}\text { Pseudomonas } \\
\text { fragi } \\
\text { IFO } 3458^{\mathrm{T}}\end{array}$ & $\begin{array}{l}\text { Ps. fragi } \\
\text { IFO } 12049\end{array}$ \\
\hline Gram stain & - & - & - & - & - & - & - & - & - & - \\
\hline Morphology \& cell size $(\mu \mathrm{m})$ & $\mathrm{R}, 0.7 \times 1.4$ & $\mathrm{R}, 0.5 \times 2.3$ & $\mathrm{R}, 0.5 \times 1.5$ & $\mathrm{R}, 0.5 \times 1.4$ & $\mathbf{R}, 0.7 \times 1.5$ & R., $0.6 \times 1.7$ & $\mathrm{R}, 0.6 \times 2.1$ & $\mathrm{R}, 0.7 \times 2.2$ & $\begin{array}{r}\mathrm{R}, 0.5 \sim 1.0 \\
\times 0.75 \sim 4.0^{\mathrm{a}}\end{array}$ & $\mathrm{R}$ \\
\hline Aerobic & + & + & $t$ & + & + & + & + & + & + & + \\
\hline Number of flagella & $\geq 5$ & $\geq 4$ & $\geq 5$ & $\geq 5$ & $\geq 4$ & $\geq 5$ & $\geq 5$ & $\geq 6$ & 1 & 1 \\
\hline Oxidase & + & + & + & + & + & + & + & + & + & + \\
\hline Catarase & + & + & + & + & + & + & + & + & + & + \\
\hline Nitrate reduction & + & - & - & - & - & - & - & - & - & - \\
\hline PHB accumulation & - & - & - & - & - & - & - & - & - & - \\
\hline Fluorescent pigments & - & - & - & - & - & - & - & - & - & - \\
\hline Production of fragin & + & + & + & + & + & + & + & + & - & - \\
\hline Utilization of fructose & + & - & - & - & - & - & - & - & + & + \\
\hline glucose & + & + & - & - & - & - & - & - & + & + \\
\hline arabinose & + & - & - & - & - & - & - & - & + & + \\
\hline sucrose & + & - & - & - & \pm & - & - & - & + & + \\
\hline \multirow{2}{*}{ Strain } & \multicolumn{10}{|c|}{$\%$ Homology with photobiotin-labeled DNA } \\
\hline & IFO 3458 & $3^{\mathrm{T}} \quad$ IFO 1204 & NR 2996 & NR 3000 & NR 2997 & NR 2998 & NR 2999 & NR 3001 & NR 3002 & NR 3003 \\
\hline Pseudomonas fragi IFO $3458^{\mathrm{T}}$ & 100 & & & & & & & & & \\
\hline Pseudomonas fragi IFO 12049 & 88 & 100 & & & & & & & & \\
\hline Pseudomonas sp. NR 2996 & 11 & 20 & 100 & & & & & & & \\
\hline Pseudomonas sp. NR 3000 & 10 & 33 & 70 & 100 & & & & & & \\
\hline Pseudornonas sp. NR 2997 & 18 & 26 & 42 & 42 & 100 & & & & & \\
\hline Pseudomonas sp. NR 2998 & 20 & 27 & 52 & 64 & 96 & 100 & & & & \\
\hline Pseudomonas sp. NR 2999 & 9 & 21 & 47 & 50 & 82 & 106 & 100 & & & \\
\hline Pseudomonas sp. NR 3001 & 6 & 8 & 22 & 41 & 78 & 92 & 32 & 100 & & \\
\hline Pseudomonas sp. NR 3002 & 5 & 7 & 28 & 44 & 70 & 74 & 34 & 97 & 100 & \\
\hline Pseudomonas sp. NR 3003 & 23 & 27 & 25 & 38 & 62 & 89 & 41 & 82 & 77 & 100 \\
\hline
\end{tabular}

T, type strain. NR 2996 and NR 3000, Ps. stutzeri like group; NR 2997, NR 2998, NR 2999, NR 3001, NR 3002 and NR 3003, Ps. alcaligenes like group. DNA homology values are expressed as \% of labeled DNA reassociated with heterologous DNA compared with that reassociated with homologous DNA (100\%). 
Fig. 1. HPLC analysis of extracts of culture broth from Pseudomonas strains.

HPLC elution types of Pseudomonas strains were as follows: (A) Ps. fragi IFO $3458^{\mathrm{T}}$ and Ps. fragi IFO 12049; (B) Pseudomonas sp. NR 2996; (C) Pseudomonas sp. NR 2997, Pseudomonas sp. NR 2998, Pseudomonas sp. NR 2999, Pseudomonas sp. NR 3001, Pseudomonas sp. NR 3002 and Pseudomonas sp. NR 3003; (D) Pseudomonas sp. NR 3000.

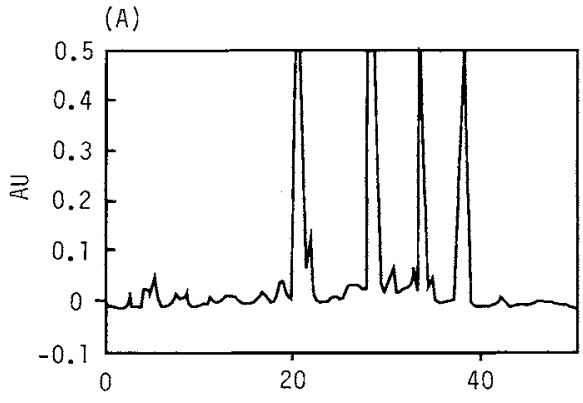

(B)

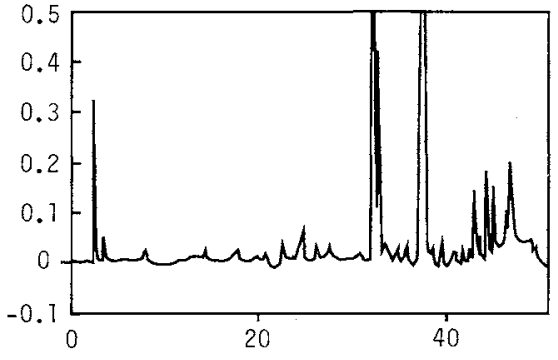

(D)

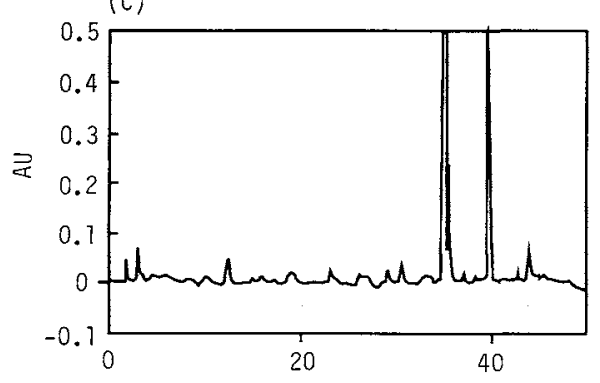

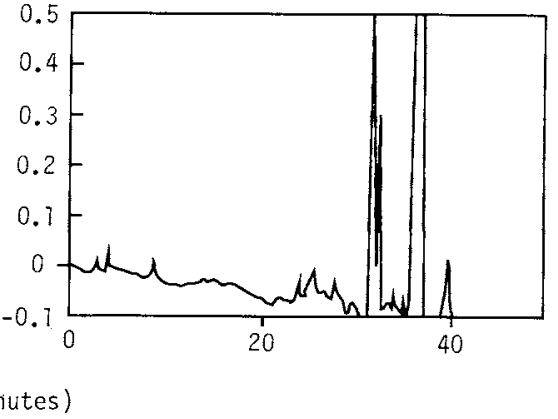

Fig. 2. RAPD patterns of Pseudomonas strains and fragin producers using primer R28.

The marks of arrowhead ( $a$ and $b$ ) are $\lambda$-DNA and 90 bp DNA, respectively.

1, NR 2996; 2, NR 2997; 3, NR 2998; 4, NR 2999; 5, NR 3000; 6, NR 3001; 7, NR 3002; 8, NR 3003; 9, Pseudomonas fragi IFO $3458^{\mathrm{T}} ; 10$, Ps. fragi IFO 12049.

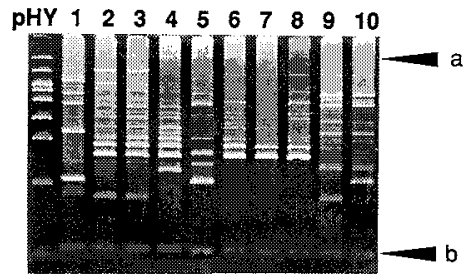

with the HPLC patterns and reflected the metabolites of strains.
Fig. 3. Dendrogram of Pseudomonas strains and fragin producers by PAUP with the bootstrap method.

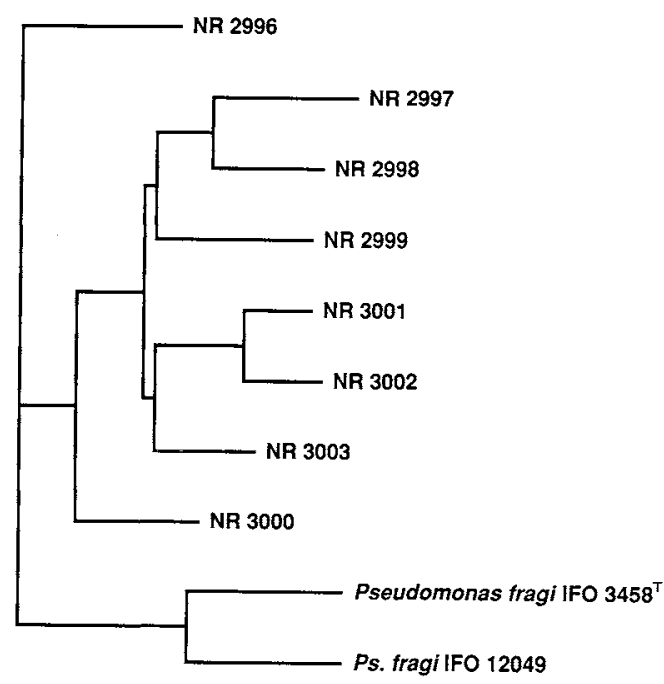

Ps. fragi IFO $3458^{\mathrm{T}}$ and IFO 12049 were in the same cluster and were regarded as one strain from the above reasoning. The results of the RAPD analysis agreed with those of morphological and physiological characteristics, DNA - DNA hybridization, and 
HPLC analysis. NR 2997 and NR 2998 were isolated from the same soil sample, and NR 3001, NR 3002, and NR 3003 were isolated from a different single sample. These five strains were located in one RAPD cluster together with NR 2999, which was isolated from a third, different soil sample (Fig. 3). The strains isolated from the same place showed a closer relatedness than did the others. This method was able to demonstrate more accurately a difference between the strains such as isolation place (Table 1). From the dendrogram derived from the RAPD pattern, we identified three strains, NR 2999, NR 2996, and NR 3000 , from among eight strains for microbial screening as independent. NR 2999 replaced the other strains in the same cluster. Although the three strains produced fragin, each strain exhibited a different HPLC pattern and had the potential to produce other active compounds in different screening procedures.

We examined twelve primers to select the optimum primer for bacterial strains using Bacillus pumilus IFO $12092^{\mathrm{T}}$ (Fig. 4); primer R28 was also suitable for Bacillus pumilus IFO $12092^{\mathrm{T}}$ (Fig. 5). R28 generated the greatest number of bands of all the primers tested, and they could be readily analyzed automatically. This result was also reproduced in other species, Arthrobacter ramosus IFO 12958 ${ }^{\mathrm{T}}$, Escherichia coli NIHJ JC-2, Flavobacterium meningosepticum IFO $12535^{\mathrm{T}}$, and Ps. fragi IFO $3458^{\mathrm{T}}$ (data not shown). Therefore, primer R28 was adopted for RAPD of bacterial strains.

We applied to RAPD with primer R28 a wide variety of thirty strains, including both Grampositive and -negative genera (Fig. 5). A number of characteristic band patterns sufficient for analysis was detected on acrylamide gels. Three different

Fig. 4. RAPD patterns of Bacillus pumilus IFO $12092^{\mathrm{T}}$ using primers $\mathrm{B} 1 \sim \mathrm{B} 11$ and $\mathrm{R} 28$.

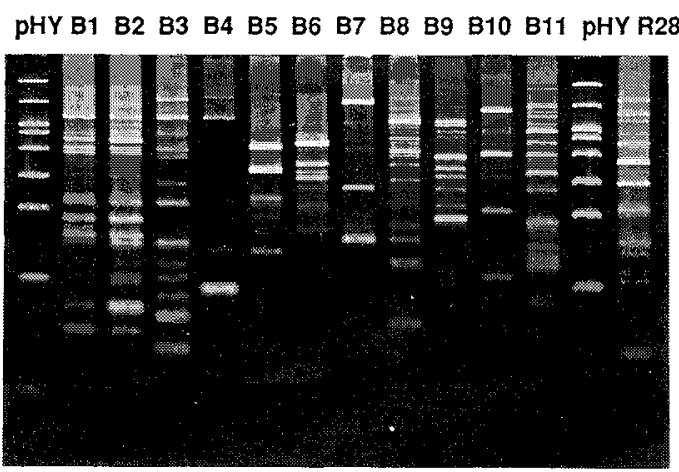

Fig. 5. RAPD patterns of various bacterial strains using primer R28.
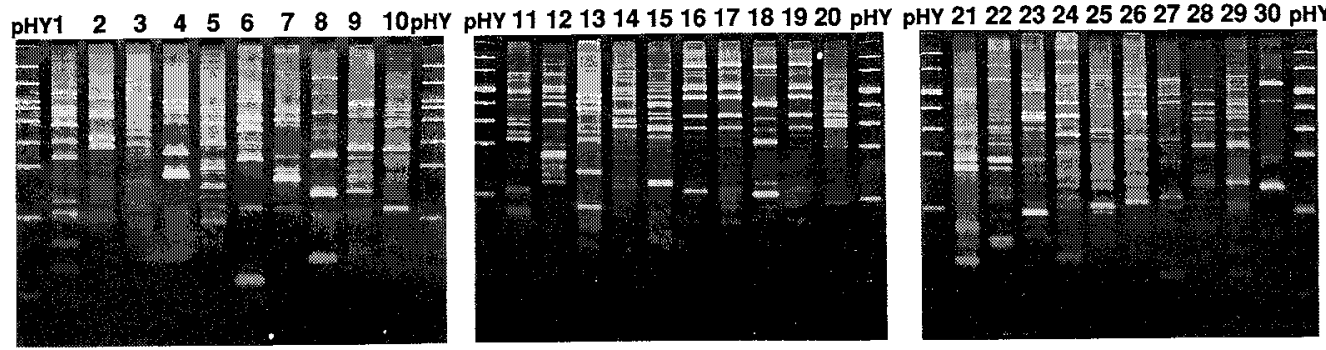

1, Acinetobacter calcoaceticus IFO 13006; 2, Aeromonas hydrophila IFO 3820; 3, Agrobacterium tumefaciens IFO 3058; 4, Shewanella putrefaciens IFO $3908^{\mathrm{T}} ; 5$, Azotobacter chroococum IFO 12994; 6, Escherichia coli NIHJ JC-2; 7, Erwinia herbicola IFO 12686; 8, Flavobacterium meningosepticum IFO $12535^{\mathrm{T}} ; 9$, Sphingobacterium spiritiborum ATCC $33861^{\mathrm{T}} ; 10$, Rhizobium leguminosarum IFO 14168; 11, Pseudomonas aerginosa A3; 12, Ps. caryophylli IFO 12952; 13, Ps. fragi IFO 3458 ${ }^{\mathrm{T}}$; 14, Comamonas testosteroni ATCC 11996 $;$; 15, Serratia liquefaciens IFO 12979; 16, Proteus vulgaris IFO 3167; 17, $P$. vulgaris ATCC $6898 ; 18, P$. vulgaris IFO $3851^{\mathrm{T}} ; 19, P$. vulgaris ATCC $6380 ; 20$, Xanthomonas campestris IFO 13551; 21, Arthrobacter ramosus IFO $12958^{\mathrm{T}} ; 22$, Bacillus laterosporus ATCC $64^{\mathrm{T}} ; 23$, B. licheniformis IFO $12200^{\mathrm{T}} ; 24$, B. pumilus IFO $12092^{\mathrm{T}} ; 25$, B. subtilis IFO $13719^{\mathrm{T}} ; 26$, Corynebacterium glutamicum ATCC 13869; 27, Corynebacterium michiganens IFO 12471; 28, Micrococcus luteus IFO $3333^{\mathrm{T}} ; 29, M$. roseus IFO $3768^{\mathrm{T}}$; 30 , Staphylococcus aureus $209 \mathrm{P}$ JC-1. 
strains of Proteus vulgaris IFO 3167, ATCC 6898, and ATCC 6380, showed similar band patterns. They had a high DNA similarity level, and their homology values were in the 80 to $92 \%$ range, although the level of similarity between $P$. vulgaris IFO $3851^{\mathrm{T}}$ and these three $P$. vulgaris strains was relatively low $(25 \sim 50 \%)$.

As shown in this study, RAPD analysis is a valuable technique to differentiate bacteria. The RAPD patterns provide an adequate means for identification and reveals information relatedness, because the dendrogram based on RAPD band patterns using fragin producers with primer R28 correlated well with the results of DNA hybridization, HPLC analysis, isolation source, and other traditional taxonomic study. The method was also applicable to a wide range of bacteria. Rapid identification by this method can exclude similar bacterial isolates by the comparison of band patterns.

\section{References}

1) Murayama, A.; K. Hata \& S. Tamura: Fragin, a new biologically active metabolite of a Pseudomonas. Part $\mathbf{I}$. Isolation, characterization and biological activities. Agric. Biol. Chem. 33: 1599 1605, 1969

2) Palleroni, N. J.: Genus Pseudomonas Migula 1894, 237 ${ }^{\mathrm{AL}}$. In Bergey's Manual of Systematic Bacterilogy. Volume 1. Eds., N. R. Krieg and J. G. Holt, pp. $141 \sim 199$, Williams \& Willkins Co., 1984

3) Frisvad, J. C. \& U. Thrane: Standardized high-performance liquid chromatography of 182 mycotoxins and other fungal metabolites based on alkylphenone retention indices and UV-VIS spectra (diode array detection). J. Chromatogr. 404: 195 214, 1987

4) Saito, H. \& K. Miura: Preparation of transforming deoxyribonucreic acid by phenol treatment. Biochim. Biophys. Acta. 72: 619 629, 1963

5) EZAKI, T.; Y. Hashimoto \& E. YABUUCHI: Fluorometric deoxyribonucleic acid-deoxyribonucleic acid hybridization in microdilution wells as an alternative to membrane filter hybridization in which radioisotopes are used to determine genetic relatedness among bacterial strains. Int. J. Syst. Bacteriol. 39: 224 229, 1989

6) ANZAI, Y.; T. OKUDA \& J. WATANABE: Application of the random amplified polymorphic DNA using the polymerase chain reaction for efficient elimination of duplicate strains in microbial screening. II. Actinomycetes. J. Antibiotics 47: $183 \sim 193,1994$

7) FuJImori, F. \& T. OKuDA: Application of the random amplified polymorphic DNA using the polymerase chain reaction for efficient elimination of duplicate strains in microbial screening. I. Fungi. J. Antibiotics 47: 173 182, 1994

8) SwofFord, D. L.: PAUP, phylogenetic analysis using parsimony, version 3.0 s. Natural History Survey, Champaign, Illinois, U.S.A. 1991 